\title{
Editorial announcement regarding new impact factor and title change
}

\section{Comunicado editorial sobre o novo fator de impacto e a mudança de nome}

Gattaz WF / Rev Psiq Clín. 2014;41(4):89

DOI: 10.1590/0101-60830000000017

\section{Dear Readers,}

On behalf of the Editorial Team, I am very pleased to make three important announcements regarding to the recent development and future challenges of the Revista de Psiquiatria Clínica.

In the first place, I am proud to announce that, according to the Institute for Scientific Information (ISI), the latest Impact Factor of the Revista de Psiquiatria Clínica has risen by almost $40 \%$, from 0.633 to 0.89 during the last year.

Today, based on the SCImago Journal Rankings of 2013, Revista de Psiquiatria Clínica, one of the most traditional psychiatric journals in South America, takes second place in Brazil and third place in all Latin America in the field of Psychiatry.

Concerning about providing scientific knowledge also for the English-speaking audience, we started to print articles preferentially in English in 2012 and from 2014 on we are only publishing manuscripts written in English. Now, to accomplish this internationalization process, I am pleased to announce the title change of our journal from "Revista de Psiquiatria Clínica” (Rev Psiq Clin; ISSN 0101-6083) to "Archives of Clinical Psychiatry (Arch Clin Psychiatry, ISSN 01016083 ). From volume 41, issue 5 , the journal will be published under this new title.
To bring authors from other continents in closer contact with our journal, I have the honor to welcome Prof. Dr. Wulf Rössler as the Regional Editor in Europe and Prof. Dr. Rodrigo MachadoVieira as the Regional Editor in the United States of America in our Editorial Team.

I would like to thank all of our Board members, authors, readers and reviewers for their ongoing support, which ensures that we continue to receive a flow of high quality research material in the field of Mental Health and hopefully will reach an impact factor above 1.0 in the near future.

In this sense, I invite you to submit your latest piece of high impact work with us on our online submission platform. We warrant a fair editorial processing and a speedy publication of accepted manuscripts.

Kind regards and thanks in advance for your contribution to the Archives of Clinical Psychiatry! 